\title{
Ideals versus Realities in the Japanese Periphery - The Case of Endogenous Development
}

\author{
SAM K. STEFFENSEN
}

Endogenous development in Japan goes back to the prewar period, but is it correct to say that it firmly took root in society when we entered the 1970s expressed by words such as "locality making" (machi zukuri) and "village awakening" (mura okoshi). Endogenous development started out as an alternative approach among regions which were being left behind during the high economic growth period or affected by its failures. The most celebrated examples are probably Ikeda town in Hokkaido prefecture, and Yufuin and Oyama towns in Oita prefecture. ${ }^{1}$

\section{Endogenous Development as Ideal}

The idea of local "development from within" (naihatsuteki hatten) became a challenging issue in Japanese regional development debates of the 1970s. From the outset it was contextually connected to progressive city government initiatives, regionalist theories, and novel revitalization activities in structurally backward localities. ${ }^{2}$ Furthermore, it gained ideological momentum from the reformed discussions on development theories taking place in the United Nations during that period. ${ }^{3}$ As a matter of course, when the Dag Hammarskjöld Foundation in 1975 applied the term "endogenous development" in a report, it gradually became accepted as a proper translation of the Japanese naihatsuteki hatten concept. ${ }^{4}$ As indicated above, to promote this notion in Japan the relatively successful pioneering examples of Ikeda, Yufuin, Oyama, including a few other localities, were always right at hand. Ikeda and Oyama town started their individual revitalization strategies in the early 1960s as a response to rural decline and poverty. Yufuin embarked on its city- 
making strategy in the early 1970s mainly as an reaction against externally imposed development projects and spreading real estate speculations. With a group of scholars subscribing to regionalism as forerunners, these localities have since the 1970s repeatedly been upheld as ideal proto-types of practical endogenous development initiatives in Japan. Much of the popular concern during this period focused on presenting the hard-data results achieved by these localities, with almost no explicit base in critical analytical frameworks. An interest in such a theoretical framework did, however, grow firmer during the 1980s, as also observed in Europe. Throughout this paper, however, I intend to argue that, in the Japanese case, the theoretical discussions on endogenous development have tilted towards abstract notions and free-wheeling traditional ideology concepts. Instead of forming a viable agenda inviting practical and forward pointing critical research results it became an arena dominated by traditional-minded scholars which work, unfortunately, rather is inviting cultural idealism and pretentious style. Furthermore, taking departure in "social reality", namely a study of depopulation issues and their public counterpolicies in present day Japan, I aim to demonstrate that the theoretical approaches of the late 1980s are not, or rather cannot be, founded on serious fieldstudies.

\section{Endogenous Development Theories in Japan}

By far the most comprehensive theory of endogenous development emerged in Japan in the late 1980s. It was presented by a group of well-reputed Japanese senior scholars among whom Tsurumi Kazuko is an intellectual founder. ${ }^{5}$ This theory, or prototheory as they argue, is in many ways a logical extension of the line of thoughts advocated by many so-called "regionalists" in the 1970s. Likewise, the pattern observed among the regionalists of the 1970s clearly repeats itself in the late 1980s, as we can observe a group of Tokyo-based scholars idealistically occupied by contriving alternative development potentials at local (peripheral) level. Reflecting general internationalization trends, however, the theoretical work of the late 1980s is now more broadly focusing on general modernization experiences in Japan as well as other Asian countries, explicitly positioning itself in opposition to a Western modernization concept. 
According to Tsurumi the concept of endogenous development is characterized by the following features :

1) The unit of modernization is the society as a whole, whose boundary coincides with the nation-state. In contrast, the unit of endogenous development is the locale, more limited and smaller than the nation-state. It is the localized network of village, town, and/or city communities, based upon the common ecological setting. Modernization represents the centralized model of development, while endogenous development stands for the decentralization model.

2) Economic growth, in terms of the size of the GNP, is the major index of modernization. In contrast, human development is the essential measure of endogenous development, and economic development, important as it is, is a condition for its realization.

3) Ecological soundness and harmony with nature is a requirement for endogenous development, whereas environmental considerations are lacking in the theory of modernization, as it is originally formulated.

4) According to the modernization theory, in order to modernize, pre-industrial traditions are to be overcome, the sooner the better. In the process of endogenous development, however, preindustrial legacies in social structure, cultural and spiritual traditions, and the forms of technology are to be renovated in such a way as to be used for rectifying and/or preventing the negative consequences of modernization.

5) The agents of modernizations are political and industrializing elites, whereas the agents of endogenous development include both elites and the common men and women of local communities, whose creativity is essential for evolving their goals and courses of development. ${ }^{6}$

The essence of Tsurumi's definition also largely conforms to the endogenous development concept which the wellknown regional economist Miyamoto (quoted earlier) encircles when he states that

A regional development, which in the hands of local administrations is improving the citizens' welfare while pursuing the development of an economy rooted in a culture where regional companies, associations, other bodies and individuals form the plans based on their own learning, originating in independent technological development, and preserving the regional environ- 
ment while making rational use of the resources, is what (I) intend to call endogenous development. ${ }^{7}$

Miyamoto, however, subsequently stresses that his use of the term (although rarely applied) does not imply a total rejection of outside capital and technology. Rather it emphasizes the importance of environmental considerations, and enlarged local autonomy embedded in democratic decision-making processes. According to Miyamoto's theoretical stance, local autonomy consciousness and active citizens' movements are the most fundamental social features to secure the preservation of environmental qualities and guarantee the "quality of life." To put Japanese development planning into a critical perspective, Miyamoto frequently turns to Western studies and discussions. Tsurumi, on the other hand, is more concerned with setting up a comparative framework in which primarily Japanese and Chinese modernization experiences may be discussed. Eventually this happens with the aim of conceiving a kind of Eastasian prototype of endogenous development promoted in sharp contrast to a stereotyped modernization theory of Western origin.

If we first take a look at Tsurumi's endogenous concept as quoted above, we observe a highly representative example of a dualistic thinking where the principles of endogenous development emerges rhetorically as a negation of the image of (Westernized) modernization. This fact alone should, I will argue, be enough to evoke one's doubt about the theory's (or proto-theory's) explanatory power and "rootedness" in contemporary critical empirical studies. As Sayer, for instance, notes

By aligning dualisms or binary oppositions in parallel it is possible to polarize whole fields of debate or characterize historical change as the supercession of one coherent block of characteristics by their opposites. What impresses us about this form of rhetoric is its symmetry and the simplicity of its basic organizational principle, rather than its descriptive or explanatory adequacy.

Such dual rhetoric was also purposely inherent in the development thinking which, for instance, Tamanoi and Kiyonari began promoting in Japan as regionalism in the 1970s in order to illuminate the contrast to the ruling national development policy. ${ }^{9}$ Now, primarily due to new directions generally taken by international 
regional development research and structural changes in the domestic agenda, Tsurumi is arguing in a more universal context. In general, though, she highlights the locale as the socio-spatial unit potentially capable of resisting the negative usurpative proceeding of modernization. In her Japanese texts she adopts the word chiiki, which literally indicates the notion of a territorially restricted space (aru tochi no haniki), as the basic unit. The exception is a brief discussion of community theory, where the word basho, meaning place, is applied. In her English presentation paper "local communities" is the favoured expression. The unit of endogenous development is characterized as being a "settled habitation" (teijuuchi) displaying mutual "values," "objectives," and "ideologies." ${ }^{10}$ According to Tsurumi, creatively drawing on the traditional thought of the Japanese ethnologist and "cultural hero" of several Japanese antimodernists, Yanagita Kunio (1875-1962), two types of social interaction (soogo sayoo) take place within such a socio-spatial unit. ${ }^{11}$ One is the interaction between the permanent residents (teijuusha), the other is the interaction between permanent residents and people coming from outside whom she prefers to call hyoohakusha, a term literally evoking a somehow traditionalized image of non-rooted persons drifting by or vagabonding. ${ }^{12}$ This presentation evidently suggests a theory conceptually founding itself upon traditional uchi/soto (inside/outside) socio-relational perceptions in a framework presupposing the actual existence of harmoniously integrated communities within spacially defined locales. The manufacture of place-based attachments and the emphasis on, in Tsurumi's words "the endogeneity and creativity of the people in defining their goals and directing their courses of development in their respective local communities" is of paramount importance. ${ }^{13}$ So far as concerns the narrow stress on local-based creativity, human development, and self-management this is, hardly surprising, a familiar echo of the common European theoretical rendering of endogenous development. For instance, as Garofoli maintains, to him endogenous development in effect means a) the capacity to transform the socialeconomic system; b) the ability to react to external challenges; $c$ ) the promotion of social learning; d) the ability to introduce specific forms of social regulations at a local level which favour the aforementioned points. Endogenous development is, in other words, the ability to innovate at a local level. ${ }^{14}$ 
As can be observed, less pompous idealistic headlines dominate the theoretical work in the European context. Such an observation sustains the assertion that a distinct feature of the Japanese theoretical current represented by Tsurumi is its deliberate abstractness as well as its idealistically compounded comparative framework (how this feature reflects empirical studies is estimated on the next pages).

Evidently, endogenous development as ideal has become a significant force among those in contemporary Japan who struggle for mobilizing local-based resources and enhanced local autonomy. Many local activities have been termed "endogenous" simply because they included some features not explicitly pointed out in national ordinances. However, in this rendering it is getting somewhat meaningless to achieve that label after the national government entirely has begun politically deploying the idea of naihatsuteki hatten, often as a fashionable euphemism applied in context with the usual ambivalent call for local attention to "special characteristics" and "self-reliance." ${ }^{15}$ In that perspective endogenous development in current Japanese regional development policy is not just confined to "filling the gaps" where exogenous development fails, but is pursued in performative co-existential socio-economic patterns of development. One can notice a politically sustained trend towards more regionally or locally organized planning and implementation of projects. This goes hand in hand with an entrepreneurial orientation towards the realization of so-called "indigenous resource potentials," whatever they may be. The institutionalized machi zukuri and mura okoshi initiatives are commonly perceived as movements in this direction, and normally deliberate stress is laid on the democratic, environmental, and welfare-related qualities of such labels. ${ }^{16}$ On that basis it seems highly appropriate to try to form a practice oriented theoretical framework which is capable of critically grasping the various local examples of endogenous initiatives in Japan, their structural problems and characteristics. Furthermore, such a framework could adequately address how and why national development policies have embraced the idea, and what the remarkable commodification of (not always pre-industrial) tradition, heritage, and nature in Japan mean to the ideals inherent in the endogenous proto-theory presented. The question is, of course, if that is what this Japanese theoretical work offers. 


\section{Japanese Endogenous Development Theory in Practice}

Characteristically, the endogenous development thinking in Japan is preoccupied with rural depopulation and other social problems, such as environmental disruption, related to the "colonizational mode of development" notably taking place during the economic high growth period. Actually, the cases where the theory of the late 1980s are concretely applied in Japan is Minamata in Kumamoto prefecture, the city devastated by mercury pollution in the 1960s, and Oyama and Yufuin Town in Oita prefecture. The theoretical work first introduced in 1989 was broad and universal in character, ostensibly aiming at making up a general socio-cultural theoretical manifesto on rural modernization issues. ${ }^{17}$ This theoretical foundation has, however, subsequently been applied in a large comparative research study project on the process of modernization of agrarian areas in contemporary Japan and China. ${ }^{18}$ In China, the collectively owned village and township industrialization in Southern Jiangsu, what is called the "Sunan model" (leaving farming without leaving home town), is studied as an endogenous development model. In Japan the village revitalization initiatives in Oita prefecture, organized and promoted by governor Hiramatsu as the "one village, one product" movement is studied as an endogenous approach generically termed as the "Oita model." In Japan, the approach of the Oita model is evidently assumed influenced by the thought of Yanagita Kunio. ${ }^{19}$ In the Chinese case, on the other hand, the ideas of the Chinese sociologist Fei Xiaotong are understood as founding a prototype for the realization of the Sunan model. ${ }^{20}$ The upbringing of "grass-root industries" in a local network of villages called "small towns," or "xiao cheng zhen" in Chinese, is the main topic for the research study on endogenous development models in China. ${ }^{21}$ Endogenous village industrialization, such as that pursued by the Sunan model, is presumed to play an important role in mitigating the drift of rural dwellers (composing almost 80 percent of the Chinese population in remarkable contrast to Japan) towards the cities in a rapidly modernizing contemporary China. Although I, along with many Japanese and Chinese scholars, critically question many of the presumptions made by this study group it is, however, beyond the scope of this paper to discuss the Chinese case studies. Instead, the 
aim is here to briefly discuss the Japanese concept constructed on the basis of local studies in Oita.

The "Oita model" presented by the study group is identical with the "one product, one village" movement advocated by governor Hiramatsu with lucid inspiration from local practices dating back to the Edo period. Tsurumi rightly recognizes that local initiatives in Japan are entirely dependent upon the existence of leader figures, whom she aptly terms "key persons." She makes a typological distinction between "theory-creative key persons" and "practiceoriented key persons," but admits that these two characteristics may often be combined within one single person. ${ }^{22}$ Additionally she introduces a so-called "policy-making key person" as a third category. This person is one "who translates the theory initiated by the theory-creative key person into a policy for its implementation."23 Naturally, this category is annexed to the theory primarily in order to explain the conspicuous cheerleader role of governor Hiramatsu (a former MITI bureaucrat), while the local leaders in representive places like Yufuin and Oyama are considered theory-creative and practice-oriented key persons. ${ }^{24}$ The practical study of Oita prefecture as a model of endogenous development, as presented in their 1991 works, is fundamentally drawn up upon Hiramatsu's local revitalization concepts entirely according to his own presentations. ${ }^{25}$ Four localities in Oita prefecture (restricted to the most celebrated) are hastily presented as case studies, but it is clearly Yufuin and Oyama which are the ones in sight. Tsurumi herself explicitly regards the brief presentations of Yufuin and Oyama as "case studies. ${ }^{26}$ Moreover, in the comparative study on Fei and Yanagita, she concludes that "endogenous development theory is unable to make progress without case research (jirei no choosa) and analysis (bunseki). ${ }^{127}$ As could be expected, this sensible feature is subsequently accentuated as contrasting with modernization theory. ${ }^{28}$ Again we can observe the flourishing dualistic rhetoric. Likewise, an underlying notion reports that centralized exogenous development is inherently boring and uniform, while decentralized endogenous development is creative, exciting, and diversified. As endogenous development seems to be understood as a vocation or sentiment rather than a rational policy, such development approaches are by nature multifarious and changeable. Exactly this "irrational" diversified dynamic is here refreshingly perceived as an exciting and attractive force. In comparison, functionalistic regional development 
theorists in Japan obviously disregard such thinking as inappropriate "civilisation theory" inclined to "emotional arguments." 29

The problem, as far as I see it, is that these functionalist scholars are in danger of being right, although largely for the wrong reasons. Surely, the endogenous development theory presented here contains several relevant and interesting ideals. The problem is rather that it is couched in obsolete dualistic rhetorical paradigms, self-generating abstractness, and traditionalized ideological concepts. Therefore this theory concept is also largely founded without convincing empirical foundation in Japan. Consequently, it is far from offering what it pretends to. As already indicated, Hiramatsu's message is just uncritically reproduced. Moreover, the case studies are not really case studies representing a scholarly, critical, and analytical piece of work which discursively provides us with insight into the specific territorial development processes, their failures and problems, socioorganizational characteristics, limitations, requirements, etc. Taking Tsurumi's own presentation of Oyama town as an example, we are offered less than one page where she mixes up the names of the leaders (to whom "special attention are paid" ${ }^{30}$ and reproduces a commonly deployed image narrative, taken from a popular work whose responsible author is left unmentioned. ${ }^{31} \mathrm{We}$ are never confronted with the problems, strategic political changes during time, socio-spacio structural preconditions, and future prospects of the town. Moreover, a focus on the most conspicuous key persons leaves us with the false impression that localities, such as Oyama, are largely homogeneous communities, which again makes it hard to understand the complex patterns of social dynamics behind their development initiatives. In short, the lack of critical methodologies and analytical empirical works makes an otherwise interesting agenda into a kind of traditionalized and impotent "show-case theory."

This despite the fact that a comprehensive Japanese analysis of this remarkable occupation with autonomous processes of development at local and regional level in Japan since the 1970s, and how this unfolded and gradually entered national policy making, would be welcome, indeed. For instance, how is the Furusato concept, which Smith considers as being "the manufacture of a quite new consciousness of native place," and which, as a national policy, is encouraging localities to think and conduct creative locality making on their own, to be evaluated by the endogenous development concept? ${ }^{32}$ And 
further, how is the socio-economic development of backward areas affected by regional policies, the spatial division of work, new modes of organizing production, advanced industrialization of intermediate regions, interchange networks, globalization, etc.? But before more critical and empirically founded case studies are presented, the theory is adding nothing qualitatively new to regional development theory and practice in Japan. One might say that it represents an universialized and generic superstructure of the many complex introspective anti-modernity sentiments, chiefly reflecting upon the Japanese experiences. The theory as such can be considered as yet another indicator of how place-making, territorial patterns of development, and endogeneity are socially valued as nice-ringing ideals in contemporary Japan. It reports how these ideals are commonly upheld as potentials of local resistance towards the negative effects and functional dependence upon modern capitalistic flows. As pointed out earlier, the notion of endogenous development in Japan has, so far, mainly been highlighted as a kind of bottom-up approach to try to counteract environmental deterioration and depopulation of rural and isolated areas. Presently, the latter issue predominates the agenda of the Japanese periphery.

\section{Down to Realities: the Depopulation Issue in Contempo- rary Japan}

At the outset of the 1970s nearly three-fourths of the national population was huddled together in cities. After a fall-off in the pace of rural outmigration during the 1970s, although without any sign of counterurbanization, the depopulation of rural and isolated areas again became a major issue from the early 1980s. By 1992 almost half $(47.7 \%)$ of the national land area was designated as depopulating area, comprising only $6.5 \%$ (approx. eight million) of the Japanese population. 1,199 or $37 \%$ of Japan's administrative entities were regarded as having problems with depopulation, among these fortyone were cities (shi), 774 were towns (machi), and 384 were villages (mura). A look into the regional structures, as shown in Table 1 below confirms that depopulation is chiefly a phenomenon of the periphery $:^{33}$ 
Sam K. Steffensen

Table 1: Depopulation According to Regional Blocks

\begin{tabular}{|c|c|c|c|}
\hline Regional block & $\begin{array}{l}\text { Share of } \\
\text { localities } \\
\text { designated } \\
\text { as } \\
\text { depopulating }\end{array}$ & $\begin{array}{l}\text { Share of } \\
\text { regional } \\
\text { population } \\
\text { implicated }\end{array}$ & $\begin{array}{l}\text { Share of total } \\
\text { designated } \\
\text { area within } \\
\text { the region }\end{array}$ \\
\hline Hokkaido & $69.3 \%$ & $17.7 \%$ & $64.0 \%$ \\
\hline Tohoku & 40.2 & 13.8 & 51.3 \\
\hline Kanto & 17.4 & 1.3 & 26.7 \\
\hline Tokai & 19.7 & 2.3 & 36.5 \\
\hline Hokuriku & 22.5 & 4.4 & 28.5 \\
\hline Kinki & 20.9 & 1.8 & 32.7 \\
\hline Chugoku & 52.8 & 12.4 & 54.5 \\
\hline Shikoku & 50.9 & 15.4 & 58.5 \\
\hline Kyushu & 53.4 & 17.5 & 60.5 \\
\hline Okinawa & 41.5 & 6.6 & 50.0 \\
\hline Total & 37.0 & 6.5 & 47.7 \\
\hline
\end{tabular}

In the 1990s a depopulation area is formally defined in terms of its actual loss of population, its population composition, and financial power. An area falling within at least one of the following categories is designated as a depopulation area according to the Special Act for Revitalizing Depopulated Areas (kasochiiki kasseika tokubetsu sochihoo) :

- Localities having experienced a ratio of population decline of more than twenty-five percent from 1960 to 1985 according to the national census. 
- Localities having a ratio of elderly ( > sixty years of age) exceeding sixteen percent according to the 1985 national census, while noting a population decline of more than twenty percent.

- Localities having a ratio of young potential working force (the cohort between fifteen and thirty years of age) of less than sixteen percent, while noting a population decline of more than twenty percent.

- Localities in which the financial power index (zaiseiryoku shisuu) within the three year period fiscal 1986 to fiscal 1988 has been constantly below 0.44 .

The Special Act for Revitalizing Depopulated Areas which originally passed as a ten year policy measure in 1970 has so far been revised twice, most recently in 1990. The passing of the Act was propelled strongly by political forces from the periphery, first of all made possible through the constructive cooperation between the Association of Governors and the Association of Assembly Chairpersons. The timing was, of course, not incidental. Between 1965-1970 a total of 867 local administrations lost more than ten percent of their population base. Moreover, the average population decline of the areas to be designated as depopulation areas according to the Act reached a historical peak of 13.1 percent. ${ }^{34}$ Prior to the enforcement of policy measures aimed at depopulated areas, acts for development of isolated islands and mountain villages had been passed in the Diet, but the Depopulation Areas Act was far more extensive. The act can be regarded as forming part of the package of public compensation or "social healing" legislations, in the words of Morito aiming for a "soft landing" (nanchakuriku), passing through the Diet during this period. ${ }^{35}$ It now makes up the most extensive measure among central government assistance schemes for development of special areas. Table 2 below is compiled to show how the act relates to the patchwork of public assistance schemes aimed at areas with structural disadvantages. The figures represent localities designated as depopulation areas. The table confirms that designated areas often overlap as well as that depopulated areas are largely composed of pheripheral, or isolated localities with little or declining industrial activity, scarce settlement space and/or tough natural settlement/living conditions. ${ }^{36}$ 
Table 2: Localities Designed for Special Public Assistance

\begin{tabular}{|c|c|c|c|c|c|c|c|c|c|c|c|}
\hline $\begin{array}{l}\text { Regional } \\
\text { Blocks }\end{array}$ & $\begin{array}{l}\text { Act for } \\
\text { Depo- } \\
\text { pulated } \\
\text { Areas }\end{array}$ & \begin{tabular}{|l|} 
New \\
Industrial \\
cities
\end{tabular} & $\begin{array}{l}\text { Act for } \\
\text { Less } \\
\text { Dev. } \\
\text { Arens }\end{array}$ & $\begin{array}{l}\text { Act for } \\
\text { Coal- } \\
\text { Minning } \\
\text { Areas }\end{array}$ & $\begin{array}{l}\text { Tech- } \\
\text { nopolis } \\
\text { Zones }\end{array}$ & $\begin{array}{l}\text { Actfor } \\
\text { Pen- } \\
\text { insulas }\end{array}$ & $\begin{array}{l}\text { Act for } \\
\text { Mour-thin } \\
\text { Village }\end{array}$ & $\begin{array}{l}\text { Act for } \\
\text { Isolz- } \\
\text { ted } \\
\text { Islands }\end{array}$ & $\begin{array}{l}\text { Act for } \\
\text { Snomvy } \\
\text { Areas }\end{array}$ & $\begin{array}{l}\text { At for } \\
\text { Peripleral } \\
\text { Areas }\end{array}$ & $\begin{array}{l}\text { Act for } S_{\text {Special }} \\
\text { Soil } \\
\text { Arcas }\end{array}$ \\
\hline Hokkaido & 147 & 1 & 30 & 30 & 0 & 23 & 91 & 6 & 147 & 120 & 0 \\
\hline Tohoku & 206 & 7 & 16 & 0 & 3 & 17 & 132 & 10 & 184 & 166 & 0 \\
\hline Kanto & 112 & 2 & 5 & 2 & 3 & 4 & 92 & 2 & 23 & 101 & 0 \\
\hline Tokai & 65 & 0 & 1 & 0 & 0 & 15 & 60 & 0 & 22 & 57 & 0 \\
\hline Hokuriku & 25 & 2 & 0 & 0 & 0 & 8 & 21 & 0 & 25 & 21 & 0 \\
\hline Kinki & 68 & 0 & 5 & 0 & 4 & 32 & 62 & 0 & 21 & 62 & 4 \\
\hline Chukoku & 168 & 3 & 30 & 4 & 6 & 10 & 127 & 23 & 58 & 157 & 99 \\
\hline Stuigoku & 110 & 5 & 14 & 0 & 1 & 7 & 72 & 13 & 0 & 99 & 76 \\
\hline Kyushtru & 276 & 18 & 48 & 48 & 25 & 74 & 90 & 54 & 0 & 206 & 128 \\
\hline Okinawa & 22 & 0 & 0 & 0 & 0 & 0 & 0 & 0 & 0 & 22 & 0 \\
\hline a. Total & 1199 & 38 & 149 & 84 & 42 & 190 & 747 & 108 & 480 & 1011 & 307 \\
\hline b. National & 1199 & 260 & 546 & 204 & 227 & 375 & 1195 & 186 & 962 & 1890 & 560 \\
\hline a. / b. (\%) & 100 & 14.6 & 27.3 & 41.2 & 18.5 & 50.7 & 62.5 & 58.1 & 49.9 & 53.5 & 54.8 \\
\hline
\end{tabular}

The Act offers centrally financed grants-in-aid for special citytown-village projects, special allocation taxes also involving the prefectures, and low interest funds for local revitalization projects conforming to the objective of the Act. In general, weight is laid on improving the living environment and the possibilities of promoting new industrial activities. Improved conditions for settlement (teijuu) and exchange (kooryuu) is on top of the agenda. During the period 1970 - 1990 the four major subjects of assistance have been as follows: 1) traffic and communication related improvements $(49.5 \% \sim$ $12,513.9$ billion yen), 2) industrial promotion ( $26 \% \sim 6,578.1$ billion yen),3) improvement of daily life environment and welfare facilities $(10.7 \% \sim 2,692.8$ billion yen), and 4) preparation of cultural and educational facilities $\left(10.5 \% \sim 2,655.5\right.$ billion yen). ${ }^{37}$ One can hardly find indicators suggesting that the Act has been successful in terms 
of its ability to mitigate the rural depopulation, a fact the National Land Agency itself is well aware of. But, as pointed out above, considerable central finances are continuously distributed to projects at grassroots level via the Act. Combined with other assistance programmes, the Act is playing an important role in facilitating daily life-related public works such as the construction of roads, schools, welfare, community and culture centers, and (increasingly) sewer systems. Public assistance programmes facilitate the initiation of essential living environment improvement projects which are neglected or continuously postponed by localities, for one thing because of their weak financial (local tax) base. Obviously, depopulated areas are especially constrained in their dispositions due to their above average dependence on public equalization taxes and subsidies, a fact outlined in Table 3 below. ${ }^{38}$

Table 3: Composition of 1991 Fiscal Revenue (in percent)

\begin{tabular}{|l|c|c|c|c|c|c|c|}
\hline & $\begin{array}{l}\text { Loca } \\
1 \\
\text { taxes }\end{array}$ & $\begin{array}{l}\text { Local } \\
\text { transfer } \\
\text { taxes }\end{array}$ & $\begin{array}{l}\text { Local } \\
\text { alloca- } \\
\text { tion taxes }\end{array}$ & $\begin{array}{l}\text { National } \\
\text { treasury } \\
\text { disburse- } \\
\text { ments }\end{array}$ & $\begin{array}{l}\text { Prefectural } \\
\text { disburse- } \\
\text { ments }\end{array}$ & $\begin{array}{l}\text { Local } \\
\text { bonds } \\
\text { (debt) }\end{array}$ & Others \\
\hline $\begin{array}{l}\text { Depopu- } \\
\text { lated } \\
\text { cities } \\
\text { /towns/ } \\
\text { villages }\end{array}$ & 10.3 & 1.6 & 44.2 & 7.5 & 9.0 & 10.9 & 16.6 \\
\hline $\begin{array}{l}\text { National } \\
\text { cities/ } \\
\text { towns/ } \\
\text { villages }\end{array}$ & 38.7 & 2.0 & 15.3 & 7.9 & 4.3 & 8.5 & 23.3 \\
\hline
\end{tabular}

The balance between local taxes (chihoozei) and local allocation taxes (chihoo koofuzei) makes up the major difference. The fashion among localities to estimate themselves as subjects of "thirty percent autonomy" (san wari jichi - as they are able to raise approximately one-third of their operating revenues through local taxation) could among depopulated areas accordingly be denoted as "ten percent autonomy." Hence, when many peripheral localities are propagandizing for economic self-reliance (jiritsu) it is fundamentally to be understood in relative terms, that is to, at least, reach up to national 
average level. The essential point to keep clear, however, is that this notion of economic self-reliance is ideologically tightly intertwined with the longstanding ambivalent ideal of self-controlled development and local autonomy, a phenomenon also called jiritsu in Japanese. ${ }^{39}$ The jiritsu meaning economic self-reliance is composed of the Chinese character signifying oneself $(j i)$, and the character here meaning to erect, set-up, or rouse oneself (ritsu). The jiritsu meaning self-controlled, on the other hand, is composed of the character signifying oneself plus the character meaning law, regulation, and control. Not surprisingly, the Economic Planning Agency's reports on regional economy are highlighting the latter jiritsu. ${ }^{40}$

It remains a fact, though, that depopulation of towns and villages in rural and isolated areas is a process which cannot be combated by present public distribution policies, although extensive efforts are mobilized. The depopulation and drift towards urban areas is continuing, hand in hand with the remarkable expansion of suburban spaces and life styles. Most of the localities suffering from depopulation are incapable of attracting industries of some significance from outside. Generally, the existing manufacturing industries as well as those being attracted are small-scale with a weak financial base (see also the following case studies). ${ }^{41}$ Moreover, the overall conditions for agricultural production are most often unfavourable. Likewise, a rapidly ageing remaining population is becoming a more and more distinct feature. By 1990 the share of elderly people $(>65$ years) in depopulated areas was $20.6 \%$ as opposed to the national average of $12.0 \%{ }^{42}$ As for residents between $15-29$ years of age, this cohort counted for $13.7 \%$ in depopulated areas, compared to the national average of $21.7 \%$. Thus, even if some of the most severely depopulated areas began rapidly to industrialize, securing an adequate labour force might very likely be a problem.

A structurally distorted population composition evidently makes depopulation a self-increasing process. For instance, the birth-rate has declined remarkably in Japan. On top of this, the generation of women between 20 - 39 years of age made up only $10.1 \%$ of the total population in depopulated areas in 1990, as opposed to a national average of $13.5 \%$. A lack of marriageable women is also quite often highlighted as a problem. In 1990 the ratio of unmarried men to women reached 2.41 in depopulated areas, while nationally being measured as $1.92 .^{43}$ One social dynamic arising on that account in many backward areas, notably in the north-western part of Japan, is 
the private import business of brides from other Asian countries, mainly the Philippines and China. This business is obviously met by various public reactions and is seldom carried out without friction. In the rural Tohoku region there have been in the early 1990s some fascinating cases where brides, imported from larger Chinese cities, have escaped from rural life in Japan soon after their arrival. Most of these have been shocked by the low standard of living, the hard work, plain foods, the boredom, and "fish-bowl"-like atmosphere, which apparently deviated considerably from their imaginative picture of "economic super-power" Japan and even made their home cities in China seem attractive. ${ }^{44}$ Such happenings, willingly covered by the mass media, provide, at best, an adequate occasion for selfreflection. But basically they show that the "awakening" projects still have a long way to go in many traditional farming areas of Japan and, moreover, that some of these public counterpolicy projects might largely have addressed the wrong issues. ${ }^{45}$ Mental backwardness and narrow-minded conservatism are very real problems in these rice producing (in Japanese sentimentally denoted as "uruoi") areas, among other things, embedded in stiff-necked agricultural politics and inhibitory organizational structures of the agro-business. In line with my argumentation earlier, it seems to me that the abstract and traditional approach of regionalists and endogenous development scholars cannot, and will not, address such issues adequately.

\section{Strategical Directions of Depopulation Countermeasures}

The population composition of depopulated areas is an increasing burden to both local administrations and central planners, challenging the principle goal of securing public provision of equal services to all Japanese according to a national minimum. For example, the standards outlined by the so-called "Gold Plan," a national ten year social welfare plan promulgated in 1990, are administratively somewhat sensitive towards local differences and special service needs of depopulated areas. Another problem in a long term perspective is that this minor share of Japanese living in depopulated areas are maintaining a large share of the national land by their cultivation of land, forestry work, and so forth. By keeping traditional ways of living, culture, and crafts alive, these minorities are 
contributing considerably to sustaining the idea of what it is to be Japanese. Hence, supported by mass media and public policy programmes, narrations opholding the social meaning of fighting depopulation and creating strategies for the revitalizing of rural communities are constantly deployed.

The outcome of such revitalization strategies depends entirely on whether new non-primary sector industrial jobs can successfully be created or otherwise secured, and whether new open, bright, and upto-date life style patterns and affluent atmospheres can convincingly be manufactured and take root in the localities. However, the mountainous geography of Japan makes the spatial issue of ultimate importance. Isolated mountain villages (as well as some island communities) make up a special problem, and many of these are evidently doomed to die out in the future. In general these places, together with isolated rural areas, have a dull image and offer impossible conditions for modern living. For less isolated places, the major tasks are to restructure the existing agricultural production, secure alternative attractive employment possibilities, and upgrade the living environment.

As Japanese agriculture's total factor productivity has stagnated since the late 1960s and growth of labour productivity lags far behind that of industry, agricultural restructuring strategies should be understood as being nothing but a supplement to local depopulation countermeasures (i.e. securing supplementary work to households). ${ }^{46}$ By far the majority of Japanese farmers are farming parttime, especially those growing rice, where little day to day maintenance is required. The overwhelmingly popular local strategic counter-reaction to the structural weakness of Japanese agriculture, and a way to seek to provide alternative employment possibilities, are the creative attempts to invent value-added (as well as imageadded) local speciality products. These attempts are frequently connected to other indigenous image creations and form part of the feverish public promotion of tourism and leisure industry. ${ }^{47}$ Roughly speaking, the development of local speciality products and tourism/leisure industries are the basic endogenous development features of the peripherical areas of Japan. Thoroughly embedded in the culture ideology of consumption, the realization of these potentials involves hard and seriously organized work which, however, can, at least temporarily, lead to noteworthy results in both economic and socio-cultural terms. ${ }^{48}$ 
The point is, however, that no matter what revitalization strategy is implemented by localities, it must be tied to larger socio-spatial networks. Promotion of easy access connections to larger cities, social exchange programmes, as well as attractive and convenient localitymaking are the basic requirements in any revitalization planning and consequently the themes on which public assistance is focusing. Guided by the outlines of the Fourth Comprehensive National Development Plan, nation-wide creations of large area interchange networks and the formation of inter-local organizations are strongly encouraged by the public development policies. A regional branch office of MITI, for example, is enthusiastically supporting the idea that Japanese locality-making in the 1990s is bound to happen in an "era of cooperation and interchange" (rengoo / kooryuu no jidai). ${ }^{49}$ Intensive functional interaction with the surrounding world is necessary to help the residents easily attain new exciting spheres of consumption, information, and leisure so highly in demand. New improved infrastructural networks enhance the possibilities of timely ("just-in-time") distribution of local products to cities, as well as being indispensable for industrial promotion campaigns. Infrastructural networks facilitate the conversion of some rural localities into potential commuter areas. Notably in the case of rural part-timefarming economies, the possibility of daily commuting to a larger city nearby is a decisive advantage. Furthermore, an interchange network between cities and rural localities is opening possibilities for tourist and leisure projects. Therefore, as previously outlined, the Depopulation Act's largest single contribution to date has been the preparation of basic physical infrastructure.

These public investments have, especially since the late 1980s, increasingly been followed up by investments in public facilities and amenities upgrading the living environment. Conforming to the ideas of the national Furusato (hometown) creation subsidy schemes, splendidly constructed public facilities including nursery and elementary schools, post offices, community centers, day-care centers, architectural landmarks, etc., are emerging in even the most far flung areas. ${ }^{50}$ The logic behind the Depopulation Act's active support of the upgrading of public facilities in depopulated and declining areas is naturally expressed as an attempt to eliminate any reason for leaving the countryside as far as concerns the provision of public (hardware) services, as well as basic measures in order to promote U or I turn activities. Public facilities are likewise increas- 
ingly recognized as playing a central role in conveying the national promotion of place-based social attachment, community morale, and the appreciation of spatial differences, traditions, cultural and natural resources. Also, it is still possible to find old elementary schools in mountanous areas providing educational services to only one student, although such arrangements in principle largely depend on the priorities of the local government concerned. One such school I visited displayed a large hand painted poster on the blackboard candidly declaring "I love (my) furusato, I love nature" (furusato ga suki, shizen ga suki) manufactured a one-page community bulletin, and shared its playground with the adjacent nursery school. The one student did, due to a skillful and sensible arrangement, twice a week attend classes in a larger school further down the mountain road in order to, as it was stated, "get accustomed to socializing with other children of the same age." preservation and revival of traditions, creation of new communal ties and exchange networks, territority-based resource mobilization and socio-economic activation in every corner of the nation is very well reflected in national regional policies addressing the depopulation issue. However, the Japanese political depopulation countermeasures are still restricted to construction works (fix capital), events, and provision of elementary public services. For example, one sees no sign of movements towards creating public assistance schemes guaranteeing a minimum personal income to residents in so-called "handicapped areas," as can be observed in some places of Western Europe.

Conspicuous and successful independent development initiatives are celebrated and eagerly supported both at local and central level. The ministries concerned issue their own brands of "locality making prizes" and designate exemplary model cases. The National Land Agency, responsible for implementing the Depopulation Act, gives away its own prizes (in Japanese: kokudochookanshoo and zenkoku kasochiiki kasseika renmeikai chooshoo) as well as introduces these superior examples (yuuryoojirei) of locality-making, chosen from among the regional blocks, in their yearly status report on depopulation. Awarding of prizes, perpetual functional area designations and network formations are all measures of a regional policy framework which enhances territorial locality-making competition and constantly raises indigenous social dynamics and resources. Obviously, an endogenous approach generating dynamics at local 
level which idealistically are bringing along enhanced territorial competitiveness and a positive sum national factor augmentation, is generally in the national government's interest. At the same time, this policy framework fosters newly enlarged possibilities and reasons for center-local cooperations. The tight fabric of horizontal linkages/networks between localities sustain both a fierce inter-local competitive environment as well as the ability to make organized demands upon the center. This highly organized competitive environment is, however, also putting an incredible pressure on special depopulated localities due to their structural weaknesses. Some localities are becoming more and more desperate and are consequently less and less fastidious about finding ways to promote local development. For one thing, this issue invites renewed considerations on what widespread enlarged local autonomy in practice could lead to, hereby putting endogenous development ideals into a critical perspective.

A more general issue, however, is the mutual imitation or creative adoptions dynamics of new locality-making and village awakening inventions. These dynamics are also seriously challenging a narrow rendering of the endogenous development ideals in Japan. Localitymaking innovations are spreading at a breathtaking pace, while showing only sporadic concern with originality or exteriorized solidarity. In Japan, several localities can easily claim to be the place of origin of the very same "local speciality" product (tokusanhin). Likewise, as soon as an original business strategy seems to enjoy prosperity one place, other entrepreneurial localities soon adopt an analogous strategy, apparently without remorse. To build local revitalization strategies up upon image creation and speciality products, which many depopulated areas are encouraged and appear confined doing, is therefore becoming increasingly difficult because of extreme competition. As the whole nation appears frantically engaged in locality making, various social aspects of this issue are increasingly coming to the attention of many Japanese scholars. For example, Iwanami and Tanaka are, in their study on local image-making, offering a well-informed discussion of the limits of these strategies accompanied by a collection of actual examples from all over Japan. ${ }^{52}$ Moreover, this setting of inter-local placemaking competitions is exceedingly pushing up conditions with transnational ramifications, notably among the Eastasian countries. 
Conforming to the sociology of globalization, the public interest in history and traditions in many localities can therefore also be seen as expressing a very commercially driven search for something verifiably original to hold on to, an originality (tradition) which can be defended and justified. It is, for instance, rather noteworthy how the furusato notion has been put into commercial use, as well as how it has been converted into physical representations in both rural and urban settings. It ought to be emphasized that rural depopulated areas are forced to create their revitalization plans in an interactive and strictly competitive environment increasingly dictated by urban value conceptions. Rural areas in Japan are gradually learning to look on themselves from a point of view which conforms to the idyllic images of urbanites, as offering healing, arranged nature, and tradition. Considerations of how city dwellers can enjoy the good side of rural life in a leisurely way and learn what it is to be Japanese are strongly present in the revitalization strategies of many depopulated rural areas.

\section{Situating Some General Perspectives - Final Comments}

In present day Japan the time-space distanciation, hyper-dynamic capitalistic space of flows, internationalization, and social diversification impose new, more complex and opaque challenges on the countryside of Japan. ${ }^{53}$ Local development approaches are increasingly based on new enhanced urban-rural interchange, larger sociospatial networks, and thriving pluralism, also making local decisionmaking processes more complicated. It eventually implies a regional policy planning tuned to the common understanding that the revival (or survival) of rural areas is bound-up in their ability to form interactive functional networks with urban milieus. Since this direction was hammered out by the Fourth Comprehensive National Development Plan various socio-economical studies on urban-rural interactions have increased in Japan, often including considerations on the consequences of a drift from a "native" or "stationary" (dochaku-gata) society to a "high mobility" (ryuudoo-gata) society. Based on that trend, I argue that instead of narrowly pursuing approaches demonstratively perceived as endogene, the new wide interactive networks seem to imply a more extroverted sense of place and multifarious strategies in constant change. It also means that it 
makes little sense to study the development approaches in any locality without paying constant attention to its structural development conditions as well as wider area socio-economic interchange networks. In an era of globalization, it should be obvious that these wider area networks in many situations appear much wider and more dynamic (unstable) in scope than to be confined to "localized networks based upon the common ecological setting" as suggested by Tsurumi. A fact, among other things, suggesting that networks ought to be studied case by case.

On that backdrop, it is equally clear that many Japanese localities remaining relatively isolated or non-awakened are, no doubt, bound for continous decline. As one result, Japanese regional social science is increasingly faced with the needs to make a methodical division based on the isolation and practiced network-structures of (depopulating) localities. Moreover, the time-honoured features of Japanese rural community (nooson) studies, often defended as the being the (only) "Japanese" in Japanese social science, are faced with scathing challenges. The practice of generally regarding Japanese rural localities as somehow secluded entities fundamentally constituted by inveterated traditional (kyoodootai) social organizational principles is increasingly misleading. Despite the fact that Japan is extremely urbanized some influential parts of Japanese regional social science have for long contributed to preserving a certain social conservatism and ideology in rural Japan. But with the rapidly increasing interactive mobility, many of the scholarly maintained dichotomies between rural and urban social organization principles are, it seems, finally about to fall apart. For example, one of the more revisionistic Tokyo-based social scientists, Hasumi, argues in a 1993 publication for the breakdown of the rigid duality between a so-called "village community-like mode of living" (sonrakuteki seikatsu yooshiki) and "urban-like mode of living" (toshiteki seikatsu yooshiki). Instead, he suggests that whether people live in a rural or urban setting they should rather be generically perceived as subject to a "modern mode of living," which eventually, in the Japanese case, is a mode of living highly dominated by urban spaces. $^{54}$ In concordance with research trends in other major industrialized nations, this line of thinking obviously represents the future direction of Japanese social science. Still then, however, one might wonder how long it takes before we see conquests of interna- 
Sam K. Steffensen

tional interest appearing from that side of the Japanese research milieu.

Sam K. Steffensen is Assistant Professor at the Department of Intercultural Communication and Management, Copenhagen Business School, and a member of the "State and Society in East Asia" Network

\section{NOTES}

1 Miyamoto Kenichi, Kankyoo Keizaigaku (Environmental Economics) (Tokyo: Iwanami Shoten, 1989).

2 For a theoretical and empirical analysis of this process refer to my Ph.D. dissertation Regional Development Issues, Localism, and the Emergence of New Social Dynamics in Contemporary Japan, (Copenhagen University, 1994). This paper is, in fact, a revised edition of chapter eight in this work (originally written as an analytical introduction to a case study).

3 This was also the forum from which the socalled "settlement concept" of the Third Comprehensive National Development Plan (promulgated in 1977) was more or less imported.

4 The 1975 Dag Hammarskjöld Report on Development and International Cooperation (prepared for the United Nations General Assembly), the Dag Hammarskjöld Foundation, Uppsala, 1975. Apparently the very first to apply the term in Japan (prior to the release of the UN report) was, in fact, the sociologist Kazuko Tsurumi in her research paper, "Yanagita Kunio's Work as a Model of Endogenous Development" (Institute of International Relations (IIR), Sophia University, 1975). See the following note.

5 Tsurumi Kazuko \& Kawata Tadashi, eds., Naihatsuteki hattenron (Theory of Endogenous Development) (Tokyo: Tokyo Daigaku Shuppankai, 1989).

6 Tsurumi Kazuko, "Aspects of Endogenous Development in Contemporary China and Japan" (Keynote Speech for the International Sociological Association's Joint Symposium, Tokyo and Kurashiki City, 1992).

7 Miyamoto Kenichi, Kankyoo Keizaigaku, p. 294.

8 Andrew Sayer, Method in Social Science: $A$ Realist Approach, 2nd, edition (London: Routledge, 1992), p. 265.

9 See for example Kiyonari Tadao, Chiikishugi no jidai (The Era of Regionalism) (Tokyo: Toyo Keizai Shinposha, 1978); Tamanoi, Kiyonari \& Nakamura, eds., Chiikishugi: atarashii shichoo he no riron to jissen no kokoromi (Regionalism: A Venture in Theory and Practice towards a New Trend of Thought) (Tokyo: Gakuyo Shobo, 1978); and Tamanoi Yoshiro, Chiikishugi no shisoo (The Ideas of Regionalism) (Tokyo: Noosangyooson Bunkakyookai, 1979).

10 Tsurumi \& Kawata, Naihatsuteki hattenron, p. 53.

11 For Yanagita as a cultural fashion and the "introspective boom" as a reaction against Japan's high economic growth modernization see Ronald A. Morse, Yanagita Kunio and the Folklore Movement: The Search for Japan's National Character and Distinctiveness (New York: Garland Publishing, 1990). According to Morse's study, Yanagita Kunio is a vital part of the Japanese quest for self-definition. For a highly fascinating interpretation of Yanagita's thought and works see the epilogue in H.D. Harootunian, Things Seen and Unseen: Discourse and Ideology in Tokugawa Nativism (Chicago: University 
of Chicago Press, 1988). Here, in relation to Yanagita's notion of "one's native place," it is, for example, mentioned that: "Yanagita's countryside was imaginary, constructed from a discourse aimed at conserving and preserving traces of a lost presence. Ethnology, which he sometimes referred to as a 'science,' became the space of discourse where he was able to constitute timeless rural Japan that was 'always already there.' In finding Japan this way, Yanagita was restoring an absent signified, rather than a different signifier that might have opened the way to a play of difference and helped subvert the prevailing ideology of the state before World War II." (p. 416).

12 Tsurumi \& Kawata, Naihatsuteki hattenron, p. 53.

13 Tsurumi, "Aspects of Endogenous Development in Contemporary China and Japan."

14 Gioacchino Garofoli, Endogenous Development and Southern Europe (Aldershot: Avebury, 1992), p. 7.

15 For an excellent analysis of how this national call played a fundamental role in the ruling ideology of the Meiji period see chapter VI in Carol Gluck, Japan's Modern Myth: Ideology in the Late Meiji Period (New Jersey: Princeton University Press, 1985).

16 For a recent example see Homma Yoshito, Machizukuri no shisoo: doboku shakai kara shimin shakai he (The Ideas of Locality Making: From Public Works Society to Civil Society) (Tokyo: Yuhikaku sensho, 1994).

17 Tsurumi \& Kawata, Naihatsuteki hattenron.

18 Uno Shigeaki and Chu Tung-Hua, eds., Noosonchiiki no kindaika to naihatsuteki hattenron (Modemization of Agrarian Areas and Endogenous Development) (Tokyo: Kokusai Shoin, 1991). The study is also published in Chinese by Jiangsu Renmin Chuban She, 1991.

19 See Tsurumi Kazuko, "Naihatsuteki hattenron no genkei: Fei Xiaotong to Yanagita
Kunio no hikaku" (Prototype of the Theory of Endogenous Development: Comparison of Fei Xiaotong and Yanagita Kunio), in Uno Shigeaki and Chu TungHua, Noosonchiiki no kindaika to naihatsuteki hattenron.

20 Fei has during his many years of research been showing great interest in concepts for the locale, the rural "soul" of China and the encouragement of industrial activities in small towns. Lately, one of his classic works has been released in an English translation, see Fei Xiaotong, From the Soit (Berkeley: University of California Press, 1992).

21 Tsurumi Kazuko, "Aspects of Endogenous Development in Contemporary China and Japan," p. 6.

22 These two categories are borrowed from the Japanese philosopher Ichii Saburo.

23 Tsurumi Kazuko, "Aspects of Endogenous Development in Contemporary China and Japan," p. 4 and Tsurumi \& Kawata, Naihatsuteki hattenron, chapter two.

24 Tsurumi Kazuko, "Aspects of Endogenous Development in Contemporary China and Japan," p. 19. Tsurumi fails to comment on the fact that in present day Japanese localities the most active leaders are enterpreneurial returnees or other types of newcomers.

25 Uno Shigeaki and Chu Tung-Hua, eds., Noosonchiiki no kindaika to naihatsuteki hattenron.

26 Tsurumi Kazuko, "Aspects of Endogenous Development in Contemporary China and Japan," p. 20.

27 In Uno Shigeaki and Chu Tung-Hua, eds., Noosonchiiki no kindaika to naihatsuteki hattenron, pp. 139-140

28 Ibid.

29 For a representative collection of this point of view, see Yada Toshifumi, ed., Chiikikoozooron no riron (Theories of $\mathrm{Re}-$ gional Structures) (Kyoto: Mineruba, 1990).

31 The work is called Oyama dokuritsukoku (Oyama, an Independent Country) re- 
commended by governor Hiramatsu and Television Oita and published by Adobansu Oita, 1982. The author seems to be unknown to the publisher as well; when I called to speak to the person responsible for the contents, they, after a little while, chose to put down the receiver.

32 Robert J. Smith, "The Cultural Context of the Japanese Political Economy," in Kumon and Rosovsky, eds., The Political Economy of Japan. Vol. 3: Cultural and Social Dynamics (Stanford: Stanford University Press,1992), p. 30.

33 The National Land Agency, Heisei yonnendoban, Kasotaisaku no genkyoo (Fiscal 1992 edition of The Present Situation of Depopulation Countermeasures) (Tokyo: 1993). The regional blocks are composed of the following prefectures: Hokkaido $=$ Hokkaido $/$ Tohoku = Aomori, Iwate, Miyagi, Akita, Yamagata, Fukushima, Niigata / Kanto = Ibaraki, Tochiki, Gumma, Saitama, Chiba, Tokyo, Kanagawa, Yamanashi, Nagano / Hokuriku = Toyama, Ishikawa, Fukui / Kinki = Shiga, Kyoto, Osaka, Hyogo, Nara, Wakayama / Chukoku = Tottori, Shimane, Okayama, Hiroshima, Yamaguchi / Shikoku = Tokushima, Kagawa, Ehime, Kochi / Kyushu = Fukuoka, Saga, Nagasaki, Kumamoto, Oita, Miyazaki, Kagoshima / Okinawa = Okinawa.

34 Ibid. p. 25. In comparison, within the period 1980-1985 the lowest average ratio of population decline in depopulated areas was recorded with $3.6 \%$. During the period 1985-1990, the rate was once again on the rise, reaching $5.7 \%$.

35 Morito Satoshi, "Kasochiiki ni okeru U-I tan seisaku o kangaeru" (Considering the U \& I Turn Policy Taking Place in the Localities) in Kasochiikimondaichoosakai, Chihooshinkoo taisakuchoosa hookokushokasochiiki ni okeru teijuusokushin hoosaku ni kansuru choosakenkyuu (Investigative Report on Local Development Policy
Measures: Research Study Concerning Promotion of Fixed Settlements in Depopulation Areas) (Tokyo: Internal Governmental Publication, 1994). See also note 45.

36 The National Land Agency, Heisei yonnendoban, Kasotaisaku no genkyoo, p. 23.

37 Ibid., p. 8.

38 Ibid., p. 47.

39 The issue first found its modern discursive setting in late Meiji period. See Carol Gluck, Japan's Modern Myth: Ideology in the Late Meiji Period. The endogenous development theory in Tsurumi Kazuko's rendering is reviving this tradition.

40 See for instance Heisei sannen chiiki keizai repo-to (1991 Report on Regional Economy) (Tokyo: Economic Planning Agency, 1991).

41 Of 596 total industries settling down in depopulated areas in 1990 (peak year) $86.7 \%$ employed less than fifty persons. Source: The National Land Agency, Heisei yonnendoban, Kasotaisaku no genkyoo, pp. 69-70.

42 Incidentally, suicide among lonely elder people in these areas is a recognized social problem. See, for example, Tsutomu Yamamoto, "Contemporary Social Problems in Japan: A Study of the Suicide and Depopulation Problems," International Journal of Japanese Sociology, No. 1 (October, 1992).

43 Source: The National Land Agency, Heisei yonnendoban, Kasotaisaku no genkyoo.

44 For some interesting reports, see Asahi Shimbun Weekly AERA, January 12, 1993 as well as November 29, 1993.

45 A sensible critical comment on the public depopulation counterpolicies and the common central-local occupation with population increase is recently offered by Morito Satoshi, the president of the Institute for Urban and Regional Development (Chiiki Soogoo Kenkyuujo). Among other things he identifies three 
basic problems inherent in the public depopulation policies which are:

1) Rigidly uniform execution of the policy measures.

2) Excessive administrative guidance towards local economic activities, for instance, resulting in boycott of fundamental competition principles.

3) A conspicuous lack of residents participation and weakening incentives to perform self-efforts. He likewise argues for the importance of supporting future life style patterns in the localities, for example, by comprehensively reconsidering the depopulation phenomenon and not just try to attract people but instead be selective and focus on attracting and nurturing "innovators," people showing obvious innovative potentials. See Morito Satoshi, "Kasochiiki ni okeru U-I ta-n seisaku o kangaeru."

46 See Cornelis L.J. Van Der Meer and Saburo Yamada, Japanese Agriculture: A Comparative Economic Analysis (London: Routledge, 1990); and Yujiro Hayami, Japanese Agriculture under Siege (Hampshire: MacMillan, 1988).

47 For Western case studies see, for instance, John Knight, "Rural Kokusaika? Foreign Motifs and Village Revival in Japan," Japan Forum, Vol. 5, No. 2 (1993); and John Knight, "Rural Revitalization in Japan: Spirit of the Village and Taste of the Country," Asian Survey, Vol. XXXIV, No. 7 (1994). For a less successful attempt see Okpyo Moon, From Paddy Field to Ski Slope: The Revitalization of Tradition in Japanese Village Life (Manchester: Manchester University Press, 1989).

48 For one thing, the skillful combination of local specialities helps prevent the emergence of too many so-called "leakages" in the local economies embarking on tourist and leisure projects.

49 MITI, Regional Promotion Department, Chiiki-zukuri wa rengoo / kooryuu no jidai (Locality-making is the Era of Cooperation and Interchange) (Kyushu
Branch Office: Internal Governmental Publication, 1990).

50 For more on the furusato notion and furusato creation in contemporary Japan, see Chee Meow Seah, Primordial Sentiments or Rational Planning: Takeshita's Furusato Creativity Concept Analyzed, Paper No. 8, Dept. of Japanese Studies, University of Singapore (Singapore, 1989); Jennifer Robertson, Native and Newcomer: Making and Remaking a Japanese City (Berkeley: California University Press, 1991); and Sam K. Steffensen, "Regional Development Issues, Localism, and the Emergence of New Social Dynamics in Contemporary Japan."

51 The place I am here referring to is an upperhamlet of Tooyoo village in Kumamoto prefecture. A place, by the way, since the early 1980s explicitly promoting itself as "shooga to ishibashi no sato " ("the village of ginger and stone bridges" - the beautifully crafted old stone bridges are cared much for and are attracting craftsmen from China to study the traditional mode of construction. Concurrently, the ginger-growing business has become very sluggish due to increasing cheap imports from the same China).

52 Iwami Toshikatsu and Tanaka Yoshiko, Chiiki ime-ji to machizukuri (LocalityMaking and Local Image) (Tokyo: Gihoodoo Shuppankaisha, 1992).

53 The "time-space distanciation" term is adopted from Anthony Giddens, see for example The Constitution of Society (Cambridge Polity Press, 1984), while Manuel Castells has applied the "capitalistic space of flows" term, for example in his The Informational City (Oxford: Basil Blackwell, 1989).

54 Hasumi Otohiko and Okuda Michihiro, 21 seiki nihon no neo-komyuniti (The NeoCommunity of 21st Century Japan) (Tokyo: Tokyo daigaku shuppankai, 1993), p. 179. 